\title{
Mediated Ownership: Capital as Media
}

\author{
Nathan Schneider \\ University of Colorado Boulder
}

PREPRINT

Media, Culture $\&$ Society 42, no. 3 (February 2020)
https://doi.org/10.1177/0163443719899035

This paper unravels opportunities that arise from regarding corporate capital as media. First, it reviews relevant overlaps between media theory and legal theory. Second, it considers cases in which capital ownership can be best understood as mediated, affective claims. Third, it explores how recognizing capital as media can open doors to constructive, creative entrepreneurship and activism - to the point of reinventing or undermining received practices of capital ownership altogether. When we think of capital ownership as mediation, we discover our institutional surroundings to be more vulnerable to critical research and more pliable to tactical intervention.

This paper has benefited from substantive input from Nabil Echchaibi, Stewart Hoover, Nicholas Evangelos Levis, and my student and faculty colleagues at $C U$ Boulder's Center on Media, Religion, and Culture.

At a 2016 membership meeting for Green Taxi Cooperative, a new competitor to Denver's legacy taxi companies and app-based ride-sharing platforms, the meaning of ownership was in question. As members of the co-op, the drivers were its owners, a status unnecessarily confirmed by the paper stock certificates the cooperative had issued. Yet the drivers, predominantly African immigrants, didn't seem to want to leave any wiggle room to the interpretation of their adopted US legal system. Recent years in the Denver taxi business had seen more than enough betrayals and reversals. Much of that early meeting was spent on a proposal to amend the bylaws to clarify, in no uncertain terms, that as members, they were also in fact owners (Schneider, 2018: 86). 
In March 2018, following a dizzying surge and then decline in cryptocurrency valuations, the blockchain startup Aragon published a nearly six-minute cinematic video called "The Fight for Freedom." Silent actors gradually converge from various walks of life toward a hilltop door that opens into blinding light. Aragon co-founder Luis Cuende explains from a flickering TV screen, "Today, we are in the first time in history that we can actually try out new governance models without the need of people getting killed, because we can try those governance models from the comfort of our sofa" (Aragon, 2018). Through possessing, trading, and programming cryptographic assets, venture capitalist Chris Burniske continues, "human activity can be governed on this international basis, without nation states, without corporations."

These contexts are distinct, yet they both exhibit experiences of owning productive capital as something less stable, and less straightforward, than what talk of ownership tends to presume in common parlance. From the perspective of a precarious immigrant community, or from the legal badlands of blockchain technology, ownership over collective productivity is restless, transformative, and creative. Such cases begin to reveal ownership as a kind of mediation - a malleable technology, a means of transmission, and a vessel of signification.

This paper unravels opportunities that arise from regarding corporate capital as media. First, it reviews relevant overlaps between media theory and legal theory. Second, it considers cases in which capital ownership can be best understood as mediated, affective claims. Third, it explores how recognizing capital as media can open doors to constructive, creative entrepreneurship and activism - to the point of reinventing or undermining received practices of capital ownership altogether.

By capital ownership, I refer to claims of dominion over productive enterprises. The most familiar and apparently clear-cut example is possessing stock in a business firm - the classic domain of capitalist activity. Yet forms of ownership also arise among such roles as nonprofit trustees, committed employees, and contributors to an open-source project. In each, vital claims are afoot regarding someone's rights to the means or ends of an enterprise. The law is typically presumed the arbiter of such claims, but they contain more than legal writ or norm. For ownership to function, it must also serve as a medium of transmission.

The argument here is not that corporate capital should be considered media exclusively, or that other legal concepts are any less amenable to being so considered. Rather, I hope to demonstrate the promise in further interchange 
between legal theory and media theory. In contexts where the rule of law is not stable or reliable, thinking in terms of media may be especially useful for understanding the meaning and function of apparently legal concepts. In Green Taxi's disruption-ravaged industry or Aragon's expected blockchain utopia, ownership is less a matter of law than of signals and their contested meanings.

Capital ownership has been a source of oppression, from its modern origins in the Atlantic slave trade and colonial corporations, as well as a bearer of liberation, as among participants in Green Taxi and Aragon. Neither interpretation has a monopoly on its affordances. When we think of capital ownership as mediation, we discover our institutional surroundings to be more vulnerable to critical research and more pliable to tactical intervention.

\section{Ontologies of ownership}

\section{In media theory}

Mitchell and Hansen (2010)'s volume Critical Terms for Media Studies does not include a chapter on media. In their introduction, the editors refer to the field as "an amorphous enterprise," and rather than remedying this they call on scholars "to exploit the ambiguity of the concept of media." We come by this ambiguity honestly, as media studies emerged as a distinct field so as to interpret the implications of ever-more rapidly evolving communications technologies - what the volume editors refer to a processes of "exteriorization and invention." If nothing else we have the word's etymology and grammar: the always in-between, a singular plural, the technologies of transmission and friction through which agents establish power relations and shared meaning.

If media could ever have been a domain restricted to a specific section of social life, they are not anymore. In her presidential address to the International Communication Association, Sonia Livingstone (2009) reflected on the ever more widespread recognition of "the mediation of everything." Media scholars could no longer simply study a set of institutions called "the media"; rapacious media logics had spread to far corners of social life. She contended, "All influential institutions in society have themselves been transformed, reconstituted, by contemporary processes of mediation." Couldry and Hepp (2016) present a similarly totalizing outlook for the age of social media: "Social theory," they contend, "is no longer viable, unless it has been, in part, transformed by media theory" (p. 3). Institutions "(such as the law)" are not merely acted on by mediation but perform it, by taking 
part in "the general representation of social reality" (p. 25). They and others add the term mediatization to describe how mediation comes to reorient aspects of social life. Institutions become media themselves. So are natural phenomena like fire and the sky, according to John Durham Peters (2015)'s view of "elemental media." The study of media has become less a specific topic and more a nearly universal analytic lens.

Most heralds of media theory's totalizing posture tend to regard this posture as a recent event. Carlos Scolari (2015) identifies the shift "from the object to the process"-from "the media" to ubiquitous, cascading representationsas hypermediation (cf. Scolari, 2008). This turn includes a mounting intensification and acceleration of media technologies, with their staggering interconnectedness and information bloat. But with the difference of degree comes a difference in kind. Far more than the study of particular tools or industries, for Scolari, "hypermediations focus on the critical constitution of the global post-modern society in a virtual/real blended territory." As mediation intensifies, its logics further entwine with the social order.

The hypermediatic turn has taken hold in the "critical constitution" of capital ownership, for instance, in the virtualization of stock exchanges and the advent of high-frequency trading, through which ownership status comes and goes through automated transactions, without human owners ever knowing themselves as such. Ownership has become so mediated that only virtual mediators can be trusted to grasp it. Hypermediatic ownership can meanwhile give rise to longings for what feels really-real, such as in the case of the legally unnecessary stock certificates issued to skeptical Green Taxi drivers, or of the large blockchain-asset holders who conclude that the safest way to store their cryptographic keys is on paper in an old-fashioned bank vault.

A further tendency of media theory's totalizing turn is a turn to practice. In contrast to earlier broadcast and print tools, social media bear the claim, at least, that the people formerly known as the audience are now "users." Now, even television watchers can attest to their agency as interpreters in public through tweets and fandoms. Scholars can no longer mainly examine media content and evaluate their reception. Thus Couldry (2004) calls for "theorizing media as practice" - "a more open and inclusive paradigm for media research than previous ones." Kember and Zylinska (2012) claim their theory of mediation as no less than a "theory of life," and that "doing media studies" should involve what they call "creative mediation": active, tactical interventions through which scholars study by shaping their media environs, 
rather than imagining they can stand aloof.

I will come back to this sense of media theory as a starting point for practice, creativity, and critical intervention in what might otherwise seem to be merely legal matters of ownership. "Merely legal" is not to suggest, however, that legal discourses surrounding capital ownership are in any way simple or settled.

\section{In legal theory}

It is a custom among lawyers to refer to property as "a bundle of rights." The slogan doesn't amount to a specific legal theory (Penner, 1995-1996), but the gist is true enough - that ownership doesn't have a precise legal meaning apart from whatever powers and responsibilities arise in a specific case. Livestock owners can act toward their animals in ways that pet owners cannot, according to many legal regimes. Renting out an apartment one owns involves a different set of responsibilities than renting out one's bike. Firm ownership is similarly contingent.

Henry Hansmann (1996)'s canonical account of "the ownership of enterprise" associates a firm's owners with rights to control it and to a share of its residual profits. Allocation of these rights varies. Holders of preferred stock relinquish control for higher-priority access to profits; members of a nonprofit cooperative may hold common stock that grants voting rights but no expectation of dividends. Hansmann distills firm ownership to these constituent mechanisms to make it precise enough to be intelligible for legal and economic analysis. But upon further inspection the precision is fleeting.

Jensen and Meckling (1976), for instance, regard firms as "legal fictions which serve as a nexus for a set of contracting relationships among individuals." Like ownership, that is, the firm is merely a shorthand for a complex of more specific contracts and transactions including employment, joint purchasing, and surplus distributions. Such an understanding has held sway in discourses surrounding the "theory of the firm" since at least the field-defining work of Coase (1937).

Another view, less inclined to reduce all collective activity to entanglements of individuals, regards the firm as a more sui generis creature with a life of its own. Chassagnon and Hollandts (2014) contend that the firm cannot in fact be owned at all, for it is a "politico-legal entity," a "social organization that is institutionalized separately from law." Shareholders may be said to own shares, perhaps, and shares engender certain rights over the corporation, 
but those rights are fewer than those that comprise classical accounts of property (e.g., Honoré, 1961). Shareholding is a financial contract, not a deed of wholesale possession and not the only claim on the firm's value and behavior. Chassagnon and Hollandts contend that the claims of employees, to take one example, should have at least comparable standing.

This multi-stakeholder view accords with a growing chorus inclined to fault the doctrine of "shareholder primacy" for over-identifying the value accruing to shares with the purpose of the firm (Stout, 2013). These critics point out that the rise of shareholder primacy didn't occur through a legislative change in the underlying law; what changed was the semiotics, the interpretations, the mutually reinforcing performances among practitioners. In this light, recent multi-stakeholder innovations (such as the benefit corporation or low-profit limited liability company) may be legally extraneous. Their most important role could be to carry out a counter-performance - signaling a departure from a presumption of shareholder value maximization that was never fully obligatory in the first place (Beckon, 2018). Corporate law involves no less signaling and performance than the courtroom law of a criminal trial.

Such performativity is even more evident among early-stage firms than established ones. Explicit term sheets in entrepreneurial finance have grown increasingly complex, diverse, and creative in recent years (Bernthal, 2019), yet I once heard a prominent venture capitalist say that he regards the details of a venture contract to be irrelevant. Startups, that is, are typically in no financial position to challenge contract provisions in court, which means that dynamics of relationship and reputation serve as more relevant enforcement mechanisms than the legal formalities.

Claims of ownership over corporate entities have been only as convincing as their tools of mediation render them. The available media for dissemination have bounded the authority and reach of lawmaking throughout recorded legal history (Vesting, 2018). Such media can mediate only to the extent that people adopt them and imbue them with significance. Even as legal theory questions the possibility of fully specifying the meaning or even existence of capital ownership, there remains a felt reality that scholars will not soon explain away. 


\section{Affects of ownership}

\section{Affective media, expressive law}

The language of affect has become a fixture of media theory in recent decades. Definitions for the term vary, gesturing together toward a kind social, prerational feeling or impulse. Affect is not reducible to particular experiences or individual people; it occurs as a kind of mediation among those who experience it. Gregg and Seigworth (2010) describe affect as what "arises in the midst of in-between-ness"- those forces that "drive us toward movement, toward thought and extension, that can likewise suspend us (as if in neutral) across a barely registering accretion of force-relations, or that can even leave us overwhelmed by the world's apparent intractability" (p. 1). And it is political. "Affect holds a key to rethinking postmodern power after ideology," writes Brian Massumi in a canonical exposition (Massumi, 1995: 104). A postmodern, hypermediated jungle, that is, elevates surges of collective feeling to sites of power once reserved for ideological sense-making. Neither trolls nor presidents see fit to define a doctrine in advance; they craft contagious moods. Their affective interplay has swelled to fill space once taken by party membership, philosophical commitments, and rational debate.

The "affective turn" in media and other fields can wander into explanatory omnipresence and vagueness; it has earned its critics (e.g., Leys, 2011). Yet given how we have seen the language of capital ownership break down under legal theory's scrutiny - into a messy bundle and perhaps wholesale nonexistence - its collective, binding, emotional content reconstitutes it into something that practitioners and observers perceive as real. The Green Taxi drivers didn't need stock certificates to be legal members of their cooperative, but the paper helped convey a necessary feeling of control. The people coding Aragon's smart contracts tried to show the value of their virtual tokens through a glimpse of what revolutionary possibilities those tokens' private keys might unlock. Business television shows rely on their cacophony of tickers, their onslaught of metaphors, the relentless barking of their hosts. Affective flows mobilize capital ownership from abstraction to facticity.

Legal theorists have noted similar patterns. For instance, discussions of "law and emotion" seek to "bring a measure of behavioral realism to the legal realm" with explorations of how emotional, affective forces shape the interpretation and exercise of the law in practice (Bandes and Blumenthal, 2012; cf. Maroney, 2006). These studies overlap with the notion of "expressive law" (Anderson and Pildes, 2000; Sunstein, 1996), which emphasizes 
legislative acts as themselves bearing not just specific rules but also such affective freight as collective moods, desires, fears, and hostilities. Legal scholars emphasize the emotional qualities of such domains as criminal law and civil rights, the stuff of courtroom dramas; the affective life of corporate law has not been a prominent topic. I contend that this is an oversight, and that the affects of capital ownership are both plentiful and significant enough to merit attention.

Brian Massumi closes his essay on "The Autonomy of Affect" (1995) by remarking on the journalistic convention that regards the stock market as a meaningful barometer by which to judge the political doings of the day. In the raw data of its ups and downs, this index of what capital ownership is worth seems to deliver a definitive interpretation of a day's events, like a soothsayer or a late-night talk-show host - an impression somehow even more reliable because it sums up the activities of market participants who are allegedly rational and self-interested, the opposite of any flighty collective spirit. Writes Massumi, "The commentators are operating under the assumption that the stock market registers affective fluctuations in adjoining spheres more directly than properly economic indicators" (p. 106). The market swings seem to carry knowledge that more difficult and revealing analysis of the lived economy cannot reach.

\section{Ownership management}

The science of managing human subjects within organizations has turned to ownership as an affective tool-quite purely affective, that is, since it usually does not involve ownership in any plainly legal sense. Francesca Gino (2015), for instance, summarizes in the Harvard Business Review findings by herself and others on "How to Make Employees Feel Like They Own Their Work." She reviews studies of hotel housekeepers told their jobs are good for their bodies, college students told their cubicles are theirs to decorate, and employees primed to think about their jobs in terms of ownership. In each case, the ownership mindset elicited higher rates of pro-social, productive behavior. In no case, however, was actual capital ownership involved in recognizably economic or legal terms.

Gino's work provides academic justification for a genre of business advice that promotes the inculcation of apparent ownership among employees (e.g., Solomon, 2014). She draws on the concept of "psychological ownership" (Pierce and Jussila, 2011), part of a broader family of "metaphorical" ownership discourses (Kamleitner, 2014) in fields such as psychology, sociology, 
and management that approach ownership as affect more than as a legal condition.

As a technique of management, psychological ownership consists of cues scattered across the workplace, intended but never fully guaranteed to inculcate the intended subjectivity. Posters, lightning arrangements, turns of phrase, attire, and more serve as media that broadcast this shared experience. And psychological ownership is not solely the purview of the worker. The influential board-governance consultant John Carver (2011) encourages a mindset of "moral ownership" among nonprofit trustees, by which they develop habits to imagine themselves as accountable to people their organization affects - even if no meaningful mechanisms of such accountability actually exist, as is common.

Even legal capital ownership appears to require psychological or affective dimensions in order to have salutary business effects. Research on employeeowned firms suggests that productivity improvements are most evident when that ownership comes with an "ownership culture" that involves participatory governance (Blasi et al., 2013). In fact, many such arrangements in the United States occur through an employee stock-ownership plan, or ESOP, which, despite the name, does not entail employees directly possessing company stock; for much of the time, the stock is held on their behalf in a trust, whose trustee is typically hired by the employer. The ESOP's claim to enact employee ownership is thus itself a mediatic arrangement as much as a legal one.

Such cases rebut the legal field's exclusive right to adjudicate questions of property. In the organizational contexts of productive capital, productive ownership arises through affective production, by way of the media at hand. Regardless of who governs the organization or reaps its profits, managers can mediate ownership experiences that instill in their charges a useful sense of pride, or the anxiety that keeps one up at night until a problem is solved. These affective territories unsettle apparent realities and present lurking opportunities.

\section{Artists of ownership}

What is the point of talking about ownership as mediation or capital as media? The value in so doing is neither merely to confirm the totalizing ambitions some media scholars have for their field nor to lay theoretical claim over a topic normally dealt with in other disciplines. Rather, this 
move presents a challenge to media studies itself to recognize that capital ownership is not as fixed and steady a reality as we tend to consider it in the industries we investigate. A media analysis can recognize the ownership of corporate capital as neither just a matter of structure (as legal theory emphasizes) nor feeling (as in an affective analysis) but a mediation of both and more. We can analyze the technologies that organize such mediation. Media research can also probe the public construction of narratives and affects around corporate capital and its ownership relations.

Such a project might begin by furthering the engagement between media and law scholars - not just around the relevance of law to "the media," but the ways in which law operates as and through mediation. One outcome of this work might be a new history of the corporation as a mediatic creature. Another should be a better understanding of how representations of ownership can shift the manifestations of its practice, with consequences for economic outcomes and cultural norms.

The opportunity, however, is not solely analytical. Along the lines of Kember and Zylinska (2012)'s call for "doing media studies" through "creative mediation," the mediation of ownership invites tactical interventions into the practice of capital ownership that could have consequences for wealth inequality and corporate accountability. For instance, if it is true (as suggested above) that the doctrine of shareholder primacy is more a cultural than a legal reality, an analysis capable of accounting for both the law and the semiotic surround could open doors for meaningful change in corporate behavior.

What forms might such creative mediation take? In the vein of PierreJoseph Proudhon (1890)'s anarchist dictum that "property is theft," some would prefer to do away with ownership altogether. While a purer anarchist version of this ambition persists, the far more influential variant in recent years has been that of Internet-enabled capitalist firms such as Uber and Spotify, which use narrative and intuitive user-experience design to supplant previously customer-owned forms of property (e.g., cars and music) with network-mediated, temporary access. Despite the disavowal of property they encourage among users, however, the firms themselves are owned in a conventional fashion by their investors. Counter-interventions could seek to make more evident to users the legal and economic realities not evident in the platforms' user experiences.

Further interventions might seek to redirect ownership toward transformative uses that undermine earlier meanings and purposes. Free Software 
and Creative Commons licenses, for instance, employ copyright regimes to invert the proprietary practices that the laws were designed to enforce (Coleman, 2013). Blockchain-based smart contracts offer the promise of decentralized autonomous organizations whose media can operate without legal incorporation statutes (De Filippi and Wright, 2018). David Ellerman (2015) contends that the law and phenomenology of employee-owned firms constitute an outright reversal of the dehumanizing "rental of persons" at work in an employer-owned firm. Even if ownership cannot be separated from its capacity for domination and should be somehow abolished, perhaps the most likely way of doing so is through the re-signification of ownership itself.

Marjorie Kelly (2012) calls for a practice of "ownership design," an art of devising firm ownership structures that will result in "generative" rather than "extractive" outcomes. And there is reason to believe that an uptick in ownership design is underway. The rise of a digital economy financed through risky venture capital has led to continuous evolution in equity and investment structures to facilitate investor-oriented entrepreneurship (Bernthal, 2019); other developments seem to veer against such tendencies. US states have begun enabling firms to incorporate as benefit corporations, inscribing a social purpose into their charters - which serves as both an internal governance mechanism and an outward consumer-marketing strategy. A network known as Zebras Unite, led by startup founders who tend not to fit the familiar White and male profile, convenes investors and companies interested in ownership arrangements that balance profit with the social impact. Even politicians have sensed that there is public appetite for ownership design. In the months leading up to announcing their candidacies for the 2020 US presidential election, Senators Kirsten Gillibrand and Elizabeth Warren each championed policies related to corporate reform-promoting employee ownership and employee representation on boards, respectively.

Media research and practice can participate in shaping this flux. Already, the media of networked platforms and protocols are part of reorganizing the terms and meanings of capital ownership. Media scholars can meanwhile identify opportunities for tactical media interventions and counter-mediations that people looking through the lenses of other fields are missing. Even if we can't fully say what capital ownership is or means, it involves mechanisms that produce inequalities of wealth, governance of ubiquitous infrastructure, and circulations of social status. If media scholars can help people better understand and challenge these apparent and disguised rules, they should. 
When we recognize capital ownership as more dexterous than simply fixed legal strictures, we recognize it as a field for intervention. More of us might then have the wherewithal to imagine ourselves as not simply rote capitalholders, or victims of others' capital-holdings, but artists of ownership.

\section{References}

Anderson ES and Pildes RH (2000) Expressive Theories of Law: A General Restatement. University of Pennsylvania Law Review 148(5): 1503. DOI: $10.2307 / 3312748$.

Aragon (2018) The Fight for Freedom. Available at: https://www.youtube. com/watch?v=AqjIWmiAidw (accessed 23 July 2018).

Bandes SA and Blumenthal JA (2012) Emotion and the Law. Annual Review of Law and Social Science 8(1): 161-181. DOI: 10.1146/annurev-lawsocsci102811-173825.

Beckon B (2018) Accountable Capitalism vs. Shareholder Primacy: Finding a Better Way. Available at: https://www.cuttingedgecapital.com/accountablecapitalism-vs-shareholder-primacy-finding-a-better-way/ (accessed 11 December 2018).

Bernthal B (2019) The Evolution of Entrepreneurial Finance: A New Typology. BYU Law Review 2018: 773.

Blasi JR, Freeman RB and Kruse DL (2013) The Citizen's Share: Putting Ownership Back into Democracy. Yale University Press. Available at: http: //books.google.com?id=hZX9AQAAQBAJ.

Carver J (2011) Boards That Make a Difference: A New Design for Leadership in Nonprofit and Public Organizations. John Wiley \& Sons. Available at: http://books.google.com?id=VwirQNRv2vgC.

Chassagnon V and Hollandts X (2014) Who Are the Owners of the Firm: Shareholders, Employees, or No One? Journal of Institutional Economics 10(1): 47-69. DOI: 10.1017/S1744137413000301.

Coase RH (1937) The Nature of the Firm. Economica 4(16): 386-405. DOI: 10.1111/j.1468-0335.1937.tb00002.x.

Coleman EG (2013) Coding Freedom: The Ethics and Aesthetics of Hacking. Princeton: Princeton University Press. Available at: https://gabriellacoleman.org/Coleman-Coding-Freedom.pdf. 
Couldry N (2004) Theorising Media as Practice. Social Semiotics 14(2): 115-132. DOI: 10.1080/1035033042000238295.

Couldry N and Hepp A (2016) The Mediated Construction of Reality. Wiley. De Filippi P and Wright A (2018) Blockchain and the Law: The Rule of Code. Harvard University Press. Available at: http://books.google.com?id= k7pTDwAAQBAJ.

Ellerman D (2015) On the Renting of Persons: The Neo-Abolitionist Case Against Today's Peculiar Institution. Economic Thought: 20.

Gino F (2015) How to Make Employees Feel Like They Own Their Work. Harvard Business Review, 7 December. Available at: https://hbr.org/2015/12/ how-to-make-employees-feel-like-they-own-their-work (accessed 12 February 2019).

Gregg M and Seigworth GJ (2010) The Affect Theory Reader. Duke University Press. Available at: http://books.google.com?id=bl0udWQii48C.

Hansmann H (1996) The Ownership of Enterprise. Cambridge, MA: Harvard University Press. Available at: http://books.google.com?id=gqRNSVn wIgC.

Honoré AM (1961) Ownership. In: Guest AG (ed.) Oxford Essays in Jurisprudence. Oxford: Oxford University Press, pp. 107-147. Available at: http://fs2.american.edu/dfagel/www/OwnershipSmaller.pdf.

Jensen MC and Meckling WH (1976) Theory of the Firm: Managerial Behavior, Agency Costs and Ownership Structure. Journal of Financial Economics 3(4): 305-360. DOI: 10.1016/0304-405X(76)90026-X.

Kamleitner B (2014) A Metaphorical Synthesis of the Impact of Ownership on Consumer Behavior. ID 2770609, SSRN Scholarly Paper, 15 December. Rochester, NY: Social Science Research Network. Available at: https:// papers.ssrn.com/abstract=2770609 (accessed 12 February 2019).

Kelly M (2012) Owning Our Future: The Emerging Ownership Revolution. San Francisco: Berrett-Koehler Publishers. Available at: http://books.google. com?id=TaN1DPwsheAC.

Kember S and Zylinska J (2012) Life After New Media: Mediation as a Vital Process. MIT Press.

Leys R (2011) The Turn to Affect: A Critique. Critical Inquiry 37(3): 434-472. DOI: 10.1086/659353. 
Livingstone S (2009) On the Mediation of Everything: ICA Presidential Address 2008. Journal of Communication 59(1): 1-18. DOI: 10.1111/j.14602466.2008.01401.x.

Maroney TA (2006) Law and Emotion: A Proposed Taxonomy of an Emerging Field. Law and Human Behavior 30(2): 119-142. DOI: 10.1007/s10979-0069029-9.

Massumi B (1995) The Autonomy of Affect. Cultural Critique (31): 83-109. DOI: $10.2307 / 1354446$.

Mitchell WJT and Hansen MBN (2010) Critical Terms for Media Studies. University of Chicago Press. Available at: http://books.google.com?id= eb4HDw0CklEC.

Penner JE (1995-1996) The Bundle of Rights Picture of Property. UCLA Law Review 43: 711-820. Available at: https://heinonline.org/HOL/P?h= hein.journals/uclalr43\&i=726 (accessed 10 December 2018).

Peters JD (2015) The Marvelous Clouds: Toward a Philosophy of Elemental Media. Chicago: University of Chicago Press.

Pierce JL and Jussila I (2011) Psychological Ownership and the Organizational Context: Theory, Research Evidence, and Application. Edward Elgar Publishing. Available at: http://books.google.com?id=g3Z7QC01oowC.

Proudhon P-J (1890) What Is Property? An Inquiry into the Principle of Right and of Government. Humboldt Publishing Company. Available at: https://theanarchistlibrary.org/library/pierre-joseph-proudhon-what-isproperty-an-inquiry-into-the-principle-of-right-and-of-governmen (accessed 17 February 2019).

Schneider N (2018) Everything for Everyone: The Radical Tradition That Is Shaping the Next Economy. New York: Nation Books.

Scolari C (2008) Hipermediaciones: Elementos para una Teoría de la Comunicación Digital Interactiva. Editorial GEDISA. Available at: http: //books.google.com?id=gDslBQAAQBAJ.

Scolari CA (2015) From (New)Media to (Hyper)Mediations. Recovering Jesús Martín-Barbero's Mediation Theory in the Age of Digital Communication and Cultural Convergence. Information, Communication $\& 5$ Society 18(9): 1092-1107. DOI: 10.1080/1369118X.2015.1018299.

Solomon M (2014) The Secret Of A Successful Company Culture: 
Spread A Sense Of Ownership. Forbes, 7 July. Available at: https://www.forbes.com/sites/micahsolomon/2014/07/07/what-aneffective-customer-service-culture-requires/ (accessed 12 February 2019).

Stout LA (2013) On the Rise of Shareholder Primacy, Signs of Its Fall, and the Return of Managerialism (in the Closet). Seattle University Law Review 36: 1169 .

Sunstein CR (1996) On the Expressive Function of Law. University of Pennsylvania Law Review 144(5): 2021. DOI: 10.2307/3312647.

Vesting T (2018) Legal Theory and the Media of Law. Cheltenham, UK: Edward Elgar. 